\title{
FAKTOR-FAKTOR YANG MEMPENGARUHI KEPATUHAN WAJIB PAJAK ORANG PRIBADI DI KPP WILAYAH JAKARTA UTARA
}

\author{
RIAN SUMARTA \\ MELIAWATI \\ Sekolah Tinggi IImu Ekonomi Trisakti Jl. Kyai Tapa No. 20, Jakarta, Indonesia \\ meliawati.1597@gmail.com
}

\begin{abstract}
The Objective of the research is to determine effect of taxpayer awareness, tax sanction, knowledge and understanding of taxation, tax socialization, service quality of tax authorities and implementation of e-filing system against individual taxpayer compliance in KPP North Jakarta area. Object used in this research is individual taxpayer have Taxpayer Registration Number and registered in KPP North Jakarta area. The samples in this research consists 118 taxpayer respondents. The method of sample in this research used conveniencesampling method. The result showed that variable taxpayer awareness, knowledege, and understanding of taxation has influenced against individual taxpayer compliance. While other variables as tax sanction, service quality of tax authorities, implementation of e-filing system, tax socialization has not influenced against individual taxpayer compliance.
\end{abstract}

Keywords: Taxpayer awareness, tax sanction, knowledge and understanding of taxation, service quality of tax authorities, tax socialization, implementation of e-filing system, taxpayer compliance

\begin{abstract}
Abstrak: Tujuan penelitian adalah untuk mengetahui apakah variabel kesadaran wajib pajak, sanksi perpajakan, tingkat kualitas pelayanan fiskus, penerapan sistem e-filing, tingkat pengetahuan dan pemahaman perpajakan, dan sosialisasi perpajakan memiliki pengaruh terhadap kepatuhan wajib pajak orang pribadi. Objek yang terdapat pada penelitian adalah wajib pajak orang pribadi memiliki NPWP di KPP wilayah Jakarta Utara. Sampel yang digunakan dalam penelitian ini sebanyak 118 responden. Metode sampel yang diterapkan adalah convenience sampling. Hasil dari penelitian menyatakan bahwa variabel kesadaran wajib pajak dan tingkat pengetahuan dan pemahaman perpajakan mempunyai pengaruh terhadap kepatuhan wajib pajak orang pribadi. Sedangkan variabel lain seperti sanksi perpajakan, penerapan sistem e-filing, kualitas pelayanan fiskus, dan sosialisasi perpajakan tidak memiliki pengaruh terhadap kepatuhan wajib pajak orang pribadi.
\end{abstract}

Kata Kunci: Kesadaran wajib pajak, sanksi perpajakan, tingkat pengetahuan dan pemahaman perpajakan, penerapan sistem e-filing, kualitas pelayanan fiskus, sosialisasi perpajakan, kepatuhan wajib pajak. 


\section{PENDAHULUAN}

Pajak merupakan beban yang harus dibayarkan dalam bentuk berupa iuran atau kewajiban yang harus dibayar oleh masyarakat kepada negara dan kewajiban tersebut akan digunakan untuk kepentingan pemerintah dalam membiayai pengeluaran negara dan masyarakat umum itu sendiri dalam memenuhi kebutuhan dalam negara. Setiap masyarakat sebagai wajib pajak diwajibkan untuk ikut berpartisipasi dalam pembayaran pajak ini agar tingkat pertumbuhan ekonomi dan pelaksanaan dalam pembangunan nasional dapat berjalan dengan baik demi menciptakan kesejahteraan negara. Dalam praktiknya, seorang wajib pajak tentu akan dilengkapi dengan Nomor Pokok Wajib Pajak yang dapat digambarkan seperti tanda pengenal yang dimiliki oleh seorang wajib dalam melaksanakan kewajiban pajak untuk melakukan pembayaran administrasi dalam urusan pajak. Sistem perpajakan yang ada dan diterapkan di negara Indonesia ini memiliki sejarah yang menjelaskan bahwa sistem dan peraturan perpajakan di Indonesia sering berubah-ubah dan melakukan perubahan atau disebut reformasi perpajakan dengan memperbaharui sistem yang digunakan untuk melakukan pemungutan pajak. Sebelumnya sistem pemungutan bersifat official assessment dan sekarang berubahmenjadi sistem self assessment seiring dengan berjlan waktu. Dalam penelitian ini, topik yang akan dibahas mengenai kepatuhan pajak orang pribadi.

Kepatuhan wajib pajak merupakan faktor yang penting dan memiliki kaitan erat dengan pendapatan yang diterima oleh negara. Hal ini dikarenaka apa bila tingkat kepatuhan dari seorang wajib pajak mengalami peningkatan, maka akan meningkatkan besarnya penerimaan yang diperoleh negara dari sektor pajak (Mutia, 2014). Beberapa kasus yang terjadi di Indonesia sekarang ini mengenai permasalahan tindak korupsi yang dilakukan oleh pejabat sebagai aparat pemerintah yang tidak melakukan tanggung jawab dengan benar atas pajak. Hal tersebut membuat tingkat kepercayaan masyarakat menurun. Masyarakat sebagai wajib pajak khawatir untuk membayar pajak. Karena permasalahan tersebut, membuat masyarakat menolak untuk membayar pajak atau melakukan penghindaran pajak. Oleh adanya hal tersebut, peneliti meneliti tentang faktorfaktor apa dapat memberi pengaruh kepatuhan dari seseorang sebagai wajib pajak orang pribadi dalam melaksanakan kewajiban pajak.

\section{Theory of Planned Behavior}

Pada tahun 1980, Ajzen menyatakan Theory of Planned Behaviour untuk pertama kali. Dalam teori ini dapat digambarkan seperti seorang wajib pajak yang tidak mau patuh dalam ketentuan perpajakan karena disebabkan oleh persepsi wajib pajak terhadap pengetahuan dan pemahaman mengenai ketentuan perpajakan yang kurang. Pengertian dari teori ini yakni teori yang menjelaskan bahwa perilaku yang dilakukan oleh seseorang yang tidak patuh atau tidak taat karena adanya pengaruh dari variabel sikap, norma subjektif, niat serta pengendalian perilaku yang dipersepsikan (Tiraada 2013). Menurut Ajzen (1991) terdapat tiga hal atau faktor yang memberikan pengaruh berupa niat dalam tata perilaku seseorang yaitu behavioral belief, normative belief, dan control belief dari ketiga faktor tersebut saling berkaitan terhadap niat dan perilaku.

\section{Kepatuhan Wajib Pajak}

Dalam penelitian Arviana (2018), kepatuhan wajib pajak berawal dari keadaan dimana seorrang masyarakat wajb pajak melaksanaka semua kewajiban perpajakan. Bentuk pembinaan yang dapat diterapkan ole aparat pajak adalah dengan senantiasa agar selalu mengingatkan wajib pajak untuk membayar dan menyampaikan laporan SPT 
sesuai dengan tata cara benar dan ketepatan waktu. Kurangnya perhatian kepada penyampaian laporan SPT wajib pajak menyebabkan kurangnya kepatuhan wajib pajak orang pribadi. Salah satu cara untuk menghadapi ketidakpatuhan ini adalah tindakan tegas dengan cara memberikan sanksi administratsi karena keterlambatan wajib pajak dalam melakukan administrasi pajaknya.

Ketidakpatuhan oleh wajib pajak yang lebih buruk dari pada sekedar tidak menyampaikan SPT tepat waktu adalah ketidakpatuhan dengan sengaja hanya melaporkan sebagian kegiatan usaha. Hal inilah yang disebut sebagai penggelapan pajak yang menyebakan kerugian negara. Alasan seorang wajib pajak melakukan hal ini tidak lain agar pajak yang dibayarkan menjadi lebih kecil.

\section{Kesadaran Wajib Pajak}

Menurut penelitian Mutia (2014), kesadaran merupakan bagian yang ada terdapat dalam diri manusia itu sendiri untuk memahami bagaimana cara menyikapi secara realita nyata. Masyarakat yang sepenuhnya sadar akan pajaknya berarti mau membayar pajak secara suakrela dan tidak adanya paksaan. Pembayaran pajak yang didasari oleh memiliki landasan hukum yang kuat seuai dengan peraturan perundang-undangan.

$\mathrm{H}_{1}$ : Terdapat pengaruh kesadaran wajib pajak terhadap kepatuhan wajib pajak.

\section{Sanksi Perpajakan}

Menurut Resmi $(2011,65)$, peraturan merupakan tata cara berupa aturan bagi seseorang berupa pengetahuan tentang apa yang seharusnya dilakukan dan yang tidak boleh dilakukan. Sanksi pajak yang dikenakan kepada wajib pajak dapat mengakibatkan kewajiba perpajakan terpenuhi. Tingginya tingkat sanksi yang dikenakan masih menandakan bahwa tingkat wajib pajak untuk taat dan patuh masih minim. Oleh karena adanya hal itu, wajib pajak masih menganggap denda serta bunga administrasi masih ringan dan kurang tegas.

$\mathrm{H}_{2}$ : Terdapat pengaruh sanksi perpajakan terhadap kepatuhan wajib pajak.

\section{Kualitas Pelayanan Fiskus}

Pelayanan fiskus yang baik, dapat mendorong seorang wajib pajak untuk memenuhi kewajiban perpajakannya. Kepuasan wajib pajak dalam mendapatkan pelayanan dari fiskus yang diharapkan akan mempunyai pengaruh terhadap kepatuhan wajib pajak orang pribadi dalam melaksanakan pajak. Tetapi tidak semua wajib pajak menikmati kualtas pelayanan tersebut disebabkan wajib pajak jarang mendatangi kantor pajak.

$\mathrm{H}_{3}$ : Terdapat pengaruh kualitas pelayanan fiskus terhadap kepatuhan wajib pajak.

\section{Tingkat Pengetahuan dan Pemahaman Perpajakan}

Tingkat pengetahuan dan pemahaman perpajakan menjelaskan aturan perpajakan memiliki kaitannya dengan pendapat wajib pajak dalam memberi ketentuan atau kriteria penilaiana dalam kesadaran untuk bayar pajak. Pemahaman dan pengetahuan wajib pajak tingkatnya masih minim. Menurut Lianty et al. (2017) jikalau pemahaman dan pengetahuannya baik, maka wajib pajak akan taat pajak.

$\mathrm{H}_{4}$ : Terdapat pengaruh tingkat pengetahuan dan pemahaman perpajakan terhadap kepatuhan wajib pajak.

\section{Penerapan Sistem E-Filing}

Sistem e-filing adalah sistem penyampaian SPT secara elektronik yang telah ditentukan oleh aparat pajak. Pelaporan pajak diproses dengan online ini dijalanklan melalui situs web Direktorat Jenderal Pajak serta dapat juga melalui situs web lain yang menyediakan jasa dalam bentuk aplikasi yang menyiapkan lapor pajak secara online. Sehingga hal ini memberikan tanggung jawab serta 
kepercayaan kepada masyarakat untuk bisa menyampaikan laporan SPT sendiri.

$\mathrm{H}_{5}$ : Terdapat pengaruh penerapan sistem efiling terhadap kepatuhan wajib pajak.

\section{Sosialisasi Perpajakan}

Sosialisasi perpajakan bisa memberi pengaruh kepada kepatuhan wajib pajak, dikarenakan dengan diselenggarakannya sosialisasi, maka wajib pajak dapat lebih mengetahui serta paham perpajakan danmudah mendapatkan informasi tentang perpajakan. Sosialisai ini bisa menambah ilmu, wawasan serta pengetahuan perihal bidang perpajakan. Namun, sosialisasi masih belum diterapkan kepada wajib pajak dengan baik dan menyeluruh.

$\mathrm{H}_{6}$ : Terdapat pengaruh sosialisasi perpajakan terhadap kepatuhan wajib pajak.

\section{METODE PENELITIAN}

Penelitian ini menggunakan objek penelitan yaitu wajib pajak orang pribadi di KPP wilayah Jakarta Utara. Metode pengumpulan data sebagai sampel penelitian yaitu convenience sampling, dimana teknik pengambilan sampel kepada responden yang secara kebetulan bertemu dengan peneliti cocok menjadi objek penelitian. Penggunaan sampel untuk penelitian ini berjumlah 118 responden.

Penelitian ini menggunakan jenis data primer, di mana teknik pengumpulan data dilaksanaka dengan cara menyebarkan kuesioner yang berisikan pertanyaan terkait variabel dependen dan independen. Penyebaran kuesioner secara langsung kepada responden dan secara online. Pengukuran variabel independen yang bisa memberi dampak pada variabel dependen tersebut diukur dengan menggunakan teknik pengukuran skala Likert. Skala Likert menyediakan lima skala berupa angka. 


\section{HASIL}

Tabel 1 Hasil Uji Statistik Deskriptif

\begin{tabular}{lcccc}
\hline \multicolumn{1}{c}{ Variabel } & Minimum & Maximum & Mean & $\begin{array}{c}\text { Std. } \\
\text { Deviation }\end{array}$ \\
\hline Kesadaran Wajib Pajak & 9 & 20 & 16,28 & 1,773 \\
Sanksi Perpajakan & 12 & 20 & 16,98 & 1,821 \\
Kualitas Pelayanan Fiskus & 12 & 25 & 19,19 & 2,172 \\
Tingkat Pengetahuan dan & 5 & 15 & 11,76 & 1,718 \\
Pemahaman Pajak & 19 & 35 & 29,13 & 3,945 \\
Penerapan Sistem E-filing & 6 & 15 & 10,93 & 1,852 \\
Sosialisasi Perpajakan & 8 & 25 & 21,49 & 2,653 \\
Kepatuhan Wajib Pajak & & & &
\end{tabular}

Tabel 2 Hasil dari Uji t

\begin{tabular}{ccc}
\hline Variabel & B & Sig. \\
\hline Konstanta & 4,999 & 0,106 \\
Kesadaran Wajib Pajak & 0,380 & 0,003 \\
Sanksi Perpajakan & 0,158 & 0,251 \\
Kualitas Pelayanan Fiskus & $-0,061$ & 0,564 \\
Tingkat Pengetahuan dan & 0,378 & 0,008 \\
Pemahaman Perpajakan & 0,072 & 0,280 \\
Penerapan Sistem E-filing & 0,206 & 0,114 \\
Sosialisasi Perpajakan & 0
\end{tabular}

Sumber: Output statistik

\section{PENUTUP}

Kesimpulan dari peneliti adalah kesadaran wajib pajak dan tingkat pengetahuan dan pemahaman perpajakan mempunyai pengaruh yang bersifat positif terhadap kepatuhan wajib pajak. Selain itu variabel lain seperti sanksi perpajakan, kualitas pelayanan fiskus, sosialisasi perpajakan dan penerapan sistem e-filing tidak mempunyai pengaruh terhadap kepatuhan wajib pajak. Keterbatasan dari penlitian ini adalah penyebaran kuesioner ini hanya dilakukan di wilayah Jakarta Utara. Peneliti berharap untuk penelitian selanjutnya dapat memperluas ruang lingkup penelitian yang lebih luas dan menambahkan variabel independen lain. 


\section{REFERENCES:}

Ajzen, Icek. 1991. Theory of Planned Behavior. Organizational Behavior and Human Decision Processes, 50(2), 179-211.

Arviana, Nerissa dan Djeni Indrawati. 2018. Faktor-faktor yang Mempengaruhi Kepatuhan Wajib Pajak Orang Pribadi. Jurnal Muara IImu Ekonomi dan Bisnis, 2(1), 146-154.

Lianty, Meiska R.A, Dini Wahjoe Hapsari, Kurnia. 2017. Pengetahuan Perpajakan, Sosialisasi Perpajakan, dan

Pelayanan Fiskus terhadap Kepatuhan Wajib Pajak. Jurnal Riset Akuntansi Kontemporer, 9(2), 55-65.

Mutia, Sri Putri Tita. 2014. Pengaruh Sanksi Perpajakan, Kesadaran Perpajakan, Pelayanan Fiskus, dan Tungkat Pemahaman terhadap Kepatuhan Wajib Pajak Orang Pribadi. Jurnal Akuntansi, 2(1).

Resmi, Siti. 2011. Perpajakan Teori dan Kasus. Jakarta: Salemba Empat.

Samadiartha, I Nyoman Doananda. 2017. Dampak Sistem E-filing, Pengetahuan Perpajakan, Sosialisasi Perpajakan, Kesadaran Wajib Pajak terhadap Kepatuhan Wajib Pajak. Jurnal Manajemen dan Bisnis, 14(1), 75-103.

Tiraada, Tryana A.M. 2013. Kesadaran Perpajakan, Sanksi Pajak, Sikap Fiskus, terhadap Kepatuhan WPOP di Kabupaten Minahasa Selatan. Jurnal EMBA, 1(3), 999-1008. 